\title{
In search of 'Other' voices: on the need for non-Western (auto)ethnographic/(auto)biographical accounts of tourist culture
}

\author{
Animesh Tripathi, Stuart Hayes and Hazel Tucker \\ Department of Tourism, University of Otago, New Zealand
}

With an increase in tourists originating from Asia, the geographies of tourism have changed considerably in recent decades. Arguably, however, tourism scholarship remains largely Western-centric. In this research note, we focus on one particular area of tourism scholarship where Western-centrism may be especially problematic: tourist culture. As part of this, we draw on a case study of 'lifestyle travel' to illustrate the need for more inclusive, diverse and non-Western-centric (auto)ethnographic/(auto)biographical studies in tourist culture scholarship. In so doing, we argue that such studies may be especially useful for capturing the stories of 'Others', thus helping to broaden our knowledge base in light of tourism's shifting geographies.

Keywords: (auto)biographical research, (auto)ethnographic research, Asian tourism, lifestyle tourism, tourist culture

\section{WESTERN-CENTRISM IN TOURISM SCHOLARSHIP}

Globalization has radically changed the geography of tourism in recent decades and, in particular, contemporary tourism has come to be characterized by increased mobilities among tourists from Asia, notably China and India (Cohen/Cohen 2012; Tucker/Hayes 2019; Tucker/Zhang 2016; Winter 2009). In spite of this shift, however, tourism literature remains largely Western-centric (Edensor/Falconer 2012; Tucker/ Hayes 2019). As Edensor/Falconer (2012) point out, until now most of the study in the field of tourism has been highly Western-centric, ignoring the contesting and diverse values encompassed in the experiences of non-Western tourists. Similarly, and further reflecting the Western-centrism in tourism scholarship, Tucker/Hayes (2019: 3) argue that "the "tourist" that research has mainly focused on is still very often conceived as coming from the Western, industrialised countries ... and the producers of tourism knowledge are largely Western scholars'.

Studies such as Edensor/Falconer (2012) and Tucker/Hayes (2019) echo earlier calls from authors such as Pritchard/Morgan (2007) and Winter (2009) for a decentring of tourism scholarship. In this, the common goal is one of confronting the pervasive Western-centrism in tourism scholarship, wherein 'Other' voices have seemingly struggled to be heard. Subsequently, and for whatever reason, an apparent lack of thickly descriptive and qualitative non-Western accounts of tourism has served to produce a somewhat limited knowledge base that fails to fully capture the nuanced insights that such accounts may bring. In line with calls for a decentring of tourism 
scholarship there is, then, a clear need for a broader knowledge base that draws on a wider range of ontologies and epistemologies (Adams 2020; Pritchard/Morgan 2007). Arguably, given its potential for a diverse range of individual and context-specific experiences, this need may be especially great when it comes to scholarship into 'tourist culture' which, in the context of this research note, is something of an umbrella term that broadly encompasses the social and cultural aspects linked to touristic experiences. Using a mini case study of 'lifestyle travel' to illustrate key points, the overall intention of this research note is arguing the importance of enabling 'Other' touristic voices to be heard in tourist culture scholarship. Moreover, the case study serves to illustrate the potential usefulness of (auto)ethnographic/biographical approaches in this endeavour.

\section{THE IMPORTANCE OF THE 'OTHER' IN TOURIST CULTURE SCHOLARSHIP}

Tourist culture may be influenced by myriad factors, including one's background, upbringing and associated cultural beliefs. Whilst similarities within and between tourists from different geographical and cultural backgrounds are likely (Chen/Chang 2015; Zhang 2018), it is also important to be cognizant of the ways in which differences manifest. As Cohen et al. (2014) explain, cultural differences between nationalities can have a powerful influence on tourist culture. They note, for example, the considerable body of work that has already been undertaken with regard to Chinese tourists and some of the ways in which Chinese tourist culture is distinct and unique (as manifested in particular attitudes, behaviours and use of information sources).

One such example from this body of work is that of Pearce et al. (2013), who sought to apply a China-centric lens to Urry's (2002) Tourist Gaze, arguing that culturally specific influences such as Confucianism and Communism play a major role in Chinese tourists' gaze. Pearce et al.'s (2013) work provides a good example to support Chang's (2015) claim that the goal of the decentring project should not be to 'discard extant theories' (ibid.: 87) but rather 'to reassess how knowledge is conceived in the first place and critically apply and/or create new conceptual lenses to represent this knowledge' (ibid.: 87).

Beyond the Chinese context, other non-Western tourists in Asia have also been the focus of attention. A prominent and early example is Pfaffenberger's (1983) study of Indigenous Sri Lankans undertaking pilgrimage, which provides an evocative account that illustrates how the very notion of travel is inexorably connected with religious modalities. In a similar vein is Graburn's (1983) work on Japanese domestic tourists which highlights some of the ways in which cultural conceptions of self, including religion, shape touristic practice. The intersection of religion and tourism is also foregrounded in Din's (1989: 552) analysis of Islam and tourism, wherein for example secular and Islamic meanings of tourism are contrasted:

The secular meaning of tourism ... implies vacation ... a relaxing and invigorating experience. But in Islam, traveling is viewed as a trying task which subjects individuals to the tests of patience and perseverance.

These studies, and others like them (for example, Yamashita 2003 on Japanese women tourists; Adams 1998 on Indonesian domestic tourists), provide a useful and certainly 
more culturally empathetic conceptual lens to assist in the decentring of tourism culture scholarship.

In general, though, research into 'Other' tourists continues to lack the sort of rich, nuanced accounts that could be afforded by interpretivist research using (auto)ethnographic/biographical approaches. Importantly, as Roth (2005: 3) suggests, if 'the individual and its society - which is the seat of the social and cultural - mutally presuppose one another', then (auto)ethnographic/(auto)biographical studies of the self may also have the propensity to provide important insights into the broader society within which the individual resides. Arguably, then, rich, thickly descriptive and culturally/context-specific qualitative accounts of tourism are likely to further add value to the overall decentring project. In other words, qualitative accounts of travel and tourism from non-Western tourists/travellers may help further address issues of Western-centrism in tourism scholarship. In particular, first-person accounts drawn from (auto)ethnographic/(auto)biographical research approaches may prove especially perspicacious in terms of understanding tourist culture in a more nuanced way.

Existing studies from disciplines such as human geography and anthropology serve as excellent examples that both reinforce the need to correct the Western bias in tourism culture scholarship and, at the same time, illustrate the potential of (auto)ethnographic/(auto)biographical research for addressing this. Edensor/Kothari (2018), for instance, provide a vivid and highly evocative biographical retelling of an overland trip between India and the UK undertaken by two Indian travellers (Kothari's parents) in the 1950s. The account gives valuable insights into some of the alternate ways and processes by which 'Other' (for example, Indian) touristic identities and experiences are manifested. In so doing, Edensor and Kothari use this account to argue for a widening of tourist culture scholarship 'to include a much broader range of tourist identities, routes and spaces' (ibid.: 713). Similarly, Din (2017) based his personal storying of Baik Kampung (that is, where domestic Malaysian tourists return to their home village) on observing how grounded autoethnographic accounts can provide a better understanding of Malay modes of tourism that differ from stereotypical Western ones (for example, 'Visiting Friends and Relatives' ('VFR') travel). In addition, whilst examining the socio-cultural implications of Japanese tourist practices in Southeast Asia, Yamashita (2008: 189) reminds us of the important need 'to pay attention to the local situations in a particular context'.

The aforementioned stories undoubtedly serve to expand our understanding of tourist culture from a more culturally nuanced viewpoint. Furthermore, such stories reinforce the methodological importance of (auto)ethnography/biography in providing a "pathway towards fostering a de-centering of Western-Anglo-centrism in tourism studies' (Adams 2020: 21). Such studies, however, are infrequently found in the literature. This raises an important question: By not thoroughly engaging with first-person, (auto)ethnographic/biographical accounts of tourist culture, what might we be 'missing'? The following 'mini case study' of 'lifestyle travel' serves to illustrate the potential openings afforded by including 'Other' (auto)ethnographic/ biographical accounts in tourism scholarship. By drawing upon Animesh Tripathi's reflections, the account also highlights the opportunities that exist, methodologically, to push past our current knowledge boundaries. 


\section{CASE STUDY: 'LIFESTYLE TRAVEL'}

\subsection{Western-centrism in 'lifestyle travel' scholarship}

For some tourists, travelling has become so important to their lifestyle that it becomes a core expression of their identity. We have come to think of tourists such as this as 'lifestyle travellers'. After conducting ethnographic interviews with a group of tourists who had been travelling for over a year, Cohen $(2010 ; 2011)$ was one of the first to specifically use the term 'lifestyle traveller'. He suggests that lifestyle travel, as a means of expression, can be broadly characterized as a profound, even romanticized, search for self. Cohen (2011: 1544) also speaks to the role of performance in lifestyle travel, specifically a 'mundane cosmopolitanism' that, for his participants, 'manifested mainly in the consumption of regional cuisine and ... the wearing of romanticised versions of "ethnic" dress'.

In a similar study employing open-ended interviews, Anderson/Erskine (2014) argue that the main motivation of lifestyle travellers is not the active pursuit of mobility for its own sake, but rather that movement is determined by an intrinsic search for personal growth, and transformation. Similar to Cohen $(2010 ; 2011)$, Anderson/Erskine (2014) found that for many lifestyle travellers the need for personal growth and transformation could be satiated through movement. For Anderson and Erskine, the need to adjust to new cultures, customs and practices was viewed by lifestyle travellers as especially important for personal growth and transformation. In this sense, lifestyle travellers appear to share some commonality with 'backpacker travellers' in terms of travel motivations (Hannam/Ateljevic 2007). However, a key difference between these different traveller types is that lifestyle travellers move beyond an episodic consumption of touristic experiences and extend it to an ongoing lifestyle practice (Cohen 2010).

With the exception of the aforementioned studies, however, there is a notable dearth of literature on lifestyle travel. Moreover, our understanding of 'lifestyle travel' remains, to date, another prime example of where travel and tourism accounts are 'exclusively focused upon the preoccupations, routes and habits of European and Anglo-American travellers' (Edensor/Kohtari 2018: 713). Added to this, conceptualizations of lifestyle travellers also broadly appear grounded in extant and often seminal studies that have sought to conceptualize and categorize tourist 'types'. In this sense, conceptualizations of lifestyle travellers appear inexorably linked to categories such as Vogt's (1976) 'wanderers', Riley's (1988) 'long term budget travellers', Cohen's (1973) 'drifters', Pearce's (1990) 'hippies' and the often-termed 'alternative tourists' (Butler 1992; Cohen 1987; Eadington/Smith 1992). Despite some notable exceptions (for example, Teo/Leong's 2006 study of Asian backpackers), these studies tend to foreground 'over-general theoretical assertions that are largely based on what some tourists [that is, 'Western' ones] from certain cultural locations do at other particular places some of the time' (Edensor/Kothari 2018: 713, emphasis original).

In short, the Western-centrism underpinning tourist culture research assumes, consciously or otherwise, that lifestyle travellers only consist of tourists who originate in the 'West'; but what of 'Other' potential lifestyle tourists, and their experiences? The first author of this article is an Indian national and considers himself, in many ways, to be a lifestyle traveller. His autobiographical reflections, which will shortly be presented and analysed, reveal important cultural insights into being and becoming a lifestyle traveller and further illustrate a crucial need for more first-person, contextspecific (auto)ethnographic/biographical accounts of tourist culture phenomena. 
Lewis-Beck et al. (2004) argue that the self can be a useful and explicit topic of investigation and, as demonstrated earlier, (auto)ethnographic/biographical accounts may be of particular relevance to tourism culture scholarship. As a research method, autobiography sits broadly within autoethnography (Reed-Danahay 2001) and provides an opportunity to 'render an account of the lived experience of the self that advances shareable understanding of common human experiences' (Johnstone 1999: 25). In the following sub-section, an edited autobiography (Denzin 1989) is presented and analysed with the aim of advancing understandings of lifestyle travel from an Indian perspective.

\subsection{Being and becoming a lifestyle traveller}

Conversations with family members about Western tourists - referred to as 'foreigners' in our household - coupled with us 'gazing' upon the behaviours of such tourists, provided the foundation for our own touristic behaviours. As a family, our travel was very much 'Western inspired' in that we indulged in expensive hotels and activities that were glorified by the media. These activities included, for example, purchasing a camera pre-trip, using the services of a tour guide, following an itinerary, and visiting places just to take a photograph for 'proof' of visit. We were, in many respects, archetypal mass tourists.

Over time, however, my knowledge about, and interest in, lifestyle travel increased because of my own interactions and experiences with such tourists. In short, my introduction to lifestyle travellers was engendered through post-colonial representations of, and experiences with, counter-cultural travellers like drifters, wanderers and hippies. These lifestyle travellers, or alternative tourists, were generally frowned upon and often considered to be a bad influence on society, with a strong, and somewhat stereotypical, association with drug use and other perceived deviant behaviour. However, my own experiences of lifestyle travellers served to counter such stereotypes and, in contrast to the deviancy one might have expected, I instead found a group of 'tourists' who were warm, open and deeply involved with the host community.

The lifestyle travellers I witnessed in my youth represented, in many ways, the long tail of the 1960s and 1970s freedom movement wherein thousands of young Westerners took the overland route passing through Istanbul, Iran, Afghanistan, Pakistan, India and Nepal in search of alternative-lifestyle destinations. These travellers, to my understanding, were an evolution of alternative tourists in that they seemed to possess some ideologies from the freedom movement but at the same time exhibited traits of modern backpacking tourists. The key difference, however, between these lifestyle travellers and modern backpackers was the degree to which travel was an enduring and central component of life. There were also some similarities between these groups of travellers, and their stories spoke to a desire to break free from the mundane, a longing for freedom and an acknowledgement of the importance of culture in touristic encounters.

Some of this 'touristic being' rubbed off on me, prompting considerable reflection about my own touristic 'self' (who I was, but also who I wanted to become). After school, I was confused about what I wanted to do or be. I was curious to learn more about the purpose or meaning of life so I travelled across India, working in different jobs, trying understand my purpose. Continual travel to new and different places, including working as an expedition guide, allowed me to meet new people and this, in turn, acted as a bridge between the host community and other travellers. Even whilst leading tours, I shunned the hotels provided in favour staying at the local homestays. 
This enabled me to engage with the local communities and provided me with a sense of belonging. Experiences such as this highlight my inclination towards 'stereotypical' lifestyle travel and other forms of alternative tourism.

On reflection, I have embodied lifestyle travel in most of my travel experiences. For example, a major life movement for me was coming to New Zealand from India for the purpose of ongoing study and travel. This move was underpinned by my desire to seek knowledge and understanding of the world and, at the same time, explore my 'self'. Travel for me, therefore, has been a purposeful process of self-exploration and understanding 'Other' non-Indian cultures. As part of this, I came to realize that, for example, slow travel - characterized by rich interactions with locals and a refrain from heavily commercialized experiences - was perhaps more rewarding (for host and guest) than constantly following planned itineraries.

Importantly, this way of travelling has also enabled me to feel connected to my roots and to the myriad traditional stories about ancient lifestyle travellers - kings, monks and other people - who left home in search of 'self' and life's meaning. Since childhood, for example, we read and were told stories about the famous king Siddharth Gautam who left his home and family in search of the causes of human suffering and, ultimately, the true meaning of life. It was his learnings on these journeys that led to him becoming known as Gautam Buddha, or, as he is commonly referred to today, Buddha. I also learned stories of the famous Moroccan traveller, Ibn Battuta, whose 'Rihla' (journey) was driven by a desire to search for knowledge in the Islamic world and beyond. Similarly, I have come to also think of Swami Vivekananda as being akin to a lifestyle traveller. Swami Vivekananda travelled extensively across India for a number of years in order to understand the religious and social diversity of the country and the issues of suffering and poverty faced by communities.

While growing up, I did not think of these stories consciously, but the accounts of these traditional lifestyle travellers left a profound mark on me in terms of shaping my ideals and values. And then, when I eventually started to encounter Western lifestyle travellers, I began to perhaps appreciate how this small group of contemporary nomads shared those same ideals and values. Thus, my experiences and interactions with lifestyle travellers, both traditional and contemporary, have served to not only (re-)shape my own immediate touristic being, but at the same time have enabled something of a personal awakening. In relating lifestyle travel to the ways in which monks, sadhus and their pupils once travelled, I have found myself being opened up to viewing lifestyle travel as culturally authentic; something that is a truer representation of what travel may mean to Indians. In my case, therefore, my own practice as a lifestyle traveller is imbued with, and influenced by, the Western lifestyle travellers and alternative tourists that I have learned about and experienced. At the same time, my embodied practice is also deeply shaped by my own cultural background, and the mythical and religious stories I was exposed to growing up. It is these stories, in particular, that have influenced my embodied practices as a lifestyle traveller.

\section{CONCLUDING THOUGHTS}

In his study of tourist performances at the Taj Mahal, Edensor (1998) concluded that theories developed in the context of Western tourists might not be applicable to non-Westerners. Yet despite non-Western tourists travelling in ever-increasing numbers, a lack of culturally specific studies (for example, in relation to tourist culture) remains, according to Cohen (2008), one of the major gaps in tourism scholarship. 
Cohen/Cohen (2015) explain that potential differences between motivations, perceptions and experiences of Western and 'Other' tourists has provoked a critique of dominant Western-centric perspectives in the theoretical traditions of tourism studies.

Using 'lifestyle travel' as an example, this research note has illustrated some of the ways in which knowledge about tourist culture remains largely underpinned by Western-centic conceptualizations. At the same time, however, the first author's brief story serves to highlight what can be gained, in terms of broadening our knowledge base, by listening to the rich, qualitative accounts of 'Other' tourists and their experiences. In reflecting on Animesh Tripathi's story, lifestyle travel is shown, from an Indian perspective at least, to be an amalgamation of Western idea(1)s and Eastern cultural learnings. This is illustrated by the similarities and differences between Western and non-Western lifestyle travellers identified in Animesh Tripathi's autobiographical account. In terms of similarities, for example, the account highlights how Indian lifestyle travellers may have particular traits or motivations in common with Western lifestyle travellers (as conceptualized by Cohen 2010; 2011 and Anderson/ Erskine 2014). Certain differences, however, are also shown, and, in common with early ethnographic accounts of non-Western travellers (for example, Graburn 1983; Pfaffenberger 1983), religion and spirituality appear central to lifestyle travellers when viewed from an Indian perspective. Whilst the case study underscores the potential differences between Indian lifestyle travellers and non-Indian/Western lifestyle travellers, there are of course likely to be many more non-Western (lifestyle) travellers who would further challenge Western/Eastern ideas of what it is to be a lifestyle traveller. Consequently, there are many more stories yet to be told and many more nuances to be gleaned. This points, therefore, to a pressing need to give 'Other' tourists voice through (auto)ethnographic/biographical research methods. Arguably, given the recent rapid growth in the number of Asian tourists, and the rise of India, for example, as an important tourist-generating region (Datta 2019), such insights are needed to add a richer and more nuanced understanding of tourist culture.

\section{REFERENCES}

Adams, K.M. (1998): Domestic tourism and nation-building in South Sulawesi, in: Indonesia and the Malay World, 26(75), 77-96.

Adams, K.M. (2020): What western tourism concepts obscure: intersections of migration and tourism in Indonesia, in: Tourism Geographies, 1-26, URL: https://doi.org/10.1080/ 14616688.2020.1765010.

Anderson, J., Erskine, K. (2014): Topophilia: a study of people, place and lifestyle travel, in: Mobilities, 9(1), 130-145.

Butler, R.W. (1992): Alternative tourism: the thin edge of the wedge, in: Smith, V.L., Eadington, W.R. (eds), Tourism Alternatives: Potentials and Problems in the Development of Tourism, Philadelphia: University of Philadelphia Press, 31-46.

Chang, T.C. (2015): The Asian wave and critical tourism scholarship, in: International Journal of Asia-Pacific Studies, 11, 83-101.

Chen, J., Chang, T.C. (2015): Mobilising tourism research in emerging world regions: contributions and advances, in: Current Issues in Tourism, 18(1), 57-61.

Cohen, E. (1973): Nomads from affluence: notes on the phenomenon of drifter-tourism, in: International Journal of Comparative Sociology, 14, 89-103.

Cohen, E. (1987): 'Alternative tourism': a critique, in: Tourism Recreation Research, 12(2), 13-18.

Cohen, E. (2008): The changing faces of contemporary tourism, in: Society, 45(4), 330-333. 
Cohen, S.A. (2010): Chasing a myth? Searching for 'self' through lifestyle travel, in: Tourist Studies, 10(2), 117-133.

Cohen, S.A. (2011): Lifestyle travellers: backpacking as a way of life, in: Annals of Tourism Research, 38(4), 1535-1555.

Cohen, E., Cohen, S.A. (2012): Current sociological theories and issues in tourism, in: Annals of Tourism Research, 39(4), 2177-2202.

Cohen, E., Cohen, S.A. (2015): Beyond Eurocentrism in tourism: a paradigm shift to mobilities, in: Tourism Recreation Research, 40(2), 157-168.

Cohen, S.A., Prayag, G., Moital, M. (2014): Consumer behaviour in tourism: concepts, influences and opportunities, in: Current Issues in Tourism, 17(10), 872-909.

Datta, B. (2019): Understanding the booking patterns of Indian outbound travellers, in: GeoJournal of Tourism and Geosites, 24(1), 246-251.

Denzin, N.K. (1989): Interpretive Biography, Vol. 17, London: SAGE Publications.

Din, K.H. (1989): Islam and tourism: patterns, issues, and options, in: Annals of Tourism Research, 16(4), 542-563.

Din, K. (2017): Returning home: a reflection on the Malaysian practice of balik kampung, in: Asian Journal of Tourism Research, 2(1), 36-49.

Eadington, W.R., Smith, V.L. (1992): Introduction: the emergence of alternative forms of tourism, in: Smith, V.L., Eadington, W.R. (eds), Tourism Alternatives: Potentials and Problems in the Development of Tourism, Philadelphia: University of Philadelphia Press, 1-12.

Edensor, T. (1998): Tourists and the Taj Mahal, Oxford: Routledge.

Edensor, T., Falconer, E. (2012): Sensuous geographies of tourism, in: Wilson, J. (ed.), The Routledge Handbook of Tourism Geographies, London: Routledge, 74-81.

Edensor, T., Kothari, U. (2018): Consuming colonial imaginaries and forging postcolonial networks: on the road with Indian travellers in the 1950s, in: Mobilities, 13(5), 702-716.

Graburn, N.H. (1983): To Pray, Pay and Play: The Cultural Structure of Japanese Tourism, Aix-en-Provence: Centre des Hautes Etudes Touristiques.

Hannam, K., Ateljevic, I. (eds) (2007): Backpacker Tourism: Concepts and Profiles, Bristol, UK: Channel View Publications.

Jensen, M. (2007): Defining lifestyle, in: Environmental Sciences, 4(2), 63-73.

Johnstone, M.J. (1999): Reflective topical autobiography: an under utilised interpretive research method in nursing, in: Collegian, 6(1), 24-29.

Lewis-Beck, M.S., Bryman, A., Futing Liao, T. (2004): The SAGE Encyclopaedia of Social Science Research Methods, Thousand Oaks, CA: SAGE Publications.

Pearce, P.L. (1990): The Backpacker Phenomenon, Townsville, Queensland: James Cook University.

Pearce, P.L., Wu, M.Y., Osmond, A. (2013): Puzzles in understanding Chinese tourist behaviour: towards a triple-C gaze, in: Tourism Recreation Research, 38(2), 145-157.

Pfaffenberger, B. (1983): Serious pilgrims and frivolous tourists: the chimera of tourism in the pilgrimages of Sri Lanka, in: Annals of Tourism Research, 10(1), 57-74.

Pritchard, A., Morgan, N. (2007): De-centring tourism's intellectual universe, or traversing the dialogue between change and tradition, in: Ateljevic, I., Pritchard, A., Morgan, N. (eds), The Critical Turn in Tourism Studies, Oxford: Elsevier, 11-28.

Reed-Danahay, D. (2001): Autobiography, intimacy and ethnography, in: Atkinson, P., Coffey, A., Delamont, S., Lofland, J., Lofland, L. (eds), Handbook of Ethnography, London: SAGE Publications, 405-425.

Riley, P.J. (1988): Road culture of international long-term budget travelers, in: Annals of Tourism Research, 15(3), 313-328.

Roth, W.-M. (2005): Auto/biography and auto/ethnography: finding the generalized other in the self, in: W.-M. Roth (ed.), Auto/Biography and Auto/Ethnography: Praxis of Research Method, Rotterdam: Sense Publishers, 3-16.

Teo, P., Leong, S. (2006): A postcolonial analysis of backpacking, in: Annals of Tourism Research, 33(1), 109-131.

Tucker, H., Hayes, S. (2019): Decentring scholarship through learning with/from each 'other', in: Tourism Geographies, 1-21. 
Tucker, H., Zhang, J. (2016): On Western-centrism and 'Chineseness' in tourism studies, in: Annals of Tourism Research, 61, 250-252.

Urry, J. (2002): The Tourist Gaze, London: SAGE Publications.

Vogt, J.W. (1976): Wandering: youth and travel behavior, in: Annals of Tourism Research, 4(1), $25-41$.

Winter, T. (2009): Asian tourism and the retreat of anglo-western centrism in tourism theory, in: Current Issues in Tourism, 12(1), 21-31.

Yamashita, S. (2003): Japanese and Balinese tourism: brides heading for the island of the Gods, in: Yamashita, S. (ed.), Bali and Beyond: Explorations in the Anthropology of Tourism, New York: Berghahn Books, 87-101.

Yamashita, S. (2008): Southeast Asian tourism from a Japanese perspective, in: Hitchcock, M., King, V., Parnwell, M. (eds), Tourism in Southeast Asia: Challenges and New Directions, Copenhagen: NIAS Press, 189-205.

Zhang, J. (2018): How could we be non-Western? Some ontological and epistemological ponderings on Chinese tourism research, in: Mura, P., Khoo-Lattimore, C. (eds), Asian Qualitative Research in Tourism: Ontologies, Epistemologies, Methodologies, and Methods, Singapore: Springer, 117-136. 